portraits and documents of entomological interest would be presented to the Society. The Presiojent read a statement as to the death of a number of distinguished Russian entomologists during 1916-20.

Prof. Poulton exhibited varieties of Pyrameis cardui, and an example of a very large Papilio, $P$. homerus F., that visits the very small flower of Asclepias curassavica ; examples of Libythea, probably $L$. larus from Tanganyika Territory, congregating perhaps before or during migration; notes on the courtship of Monomotarpa insignis Distant; Coprid beetles believed to be internal parasites, and expressed the view that such cases were due to trickery on the part of native medicine men. Comments were made by the President and Mr. Durrant. Mr. Donisthorpe exhibited a specimen of Argynnis euphrosyne carrying a portion of the pupa case. Some discussion arose as to the effect of damage to antennae on the flight of butterflies. Dr. Gahan exhibited examples of the larvae of Phytodecta viminalis, and called attention to the existence in these larvae of eversible glandular structures between the seventh and eighth dorsal segments. Comments were made by Mr. C. B. Williams, who said that he had found $P$. viminalis to be viviparous. Mr. Morice exhibited:-(1) examples of Anthophora pilipes, of which he had seen no $ᄋ$ 오, and described attempts made by the $\delta$ to pair with $q 9$ of the Humble Bee ; (2) a of sawfly, T'enthredopsis palmata Geoffr. with an abnormal wing neuration, apparently a reversion to a primitive type. Mr. Talbot, on behalf of Mr. J. J. Joicey exhibited examples of Heliconius from Venezuela. Dr. Dixey, Pierines from Central Peru. Comments were made by the President, Prof. Poulton, and Mr. Rosenberg.

Two papers were read:-(1) By Mr. Donisthorpe on "Mimicry of Ants by other Arthropods," and the author exhibited a number of examples to illus. trate this. Comment was made by Prof. Poulton. (2) By Mr. G. J. Arrow on "Erotylid Coleoptera."

It was decided not to hold the informal meeting arranged for June 15th.

\title{
NEUROPTERA, MECOPTERA, AND ODONATA FROM MESOPOTAMIA AND PERSIA.
}

BY KENNETH J. MORTON, F.E.S.

\section{Plate II.}

In addition to the Odonata from Mesopotamia and North-Western Persia mentioned in the "Entomologist's Monthly Magazine," 1919 (pp. 143-151, 183-196) and 1920 (pp. 82-87), a considerable number of other Neuroptera (in the Linnean sense) were collected by Buxton and Evans. The true Neuroptera, Mecoptera, and some additional Odonata are recorded in the present paper. Through the kindness of $\mathrm{Mr}$. Waterston, I have also examined a collection made by Lt.-Col. H. D. Peile, I.M.S., in Mesopotamia, Kurdistan, and West Persia, presented by him to the British Museum, and containing some interesting species not represented in the other collections. 
Buxton in the "Entomologist's Record," 1921, in a paper on the Butterflies of Gilan, N.W. Persia, gives some information regarding the forest area of the southern Caspian, in which Enzeli, Resht, and Tula Rud are situated. The other Persian localities mentioned below are Kazvin, south of the Elburz on the plateau, Harunabad near Kermanshah, and Harir in N.W. Persia. All other localities are in Mesopotamia, excepting Suleimanyeh in Kurdistan.

As I have already indicated, the true Neuroptera from the Caspian region are quite European in character. Perhaps the most noteworthy of those from Mesopotamia are two species of Gepus, a genus of Myrmeleonidae founded by Navás on an Egyptian insect.

\section{NEUROPTERA.}

Ascalaphidae.

Helicomitus dicax Walk.

1 ㅇ, Amara, 9.vi.18 (Buxton); 1 우 on dead vegetation in dried-up marsh 12 miles below Amara, 11.ix.18 (Evans).

A larva found by Evans at Kizil Robat under a clod (22.xii.18) is very likely referable to this species, as it agrees well with Westwood's figure reproduced by Sharp in "Cambridge Natural History," vol. v, p. 461.

\section{Mrrmeleonidae.}

\section{Palpares libelluloides Linné.}

2 우, Kazvin, 20-21.vii.19; fairly common on stony desert (Buxton). 1 q, Kizil Robat, 450', 6.v.19: “ant-lion imago first emerged" (Peile); this example is rather small, the ante-apical spots larger than usual and confluent; the dark lateral line on the abdomen indistinct, but this may be due to immaturity. Although not taken by Buxton in Mesopotamia, he writes that he saw what appeared to be this species at Mendali, just on the Persian border, also flying in stony desert in bright fierce sun at 9 a.m. in July 1918.

Also 1 o , 2 ㅇ ㅇ , 12-15.vii.18, Harir, N.W. Persia, 5300 ft. (Peile).

Formicaleo tetragrammicus Fabr.

3, Enzeli, 21.vi, 30.vi.19.

\section{Nelees mesopotamiae, n. sp.}

Face yellowish with a fuscous line in front of the antennae and one behind them, followed by a pale transverse line; spots on the vertex apparently more or less confluent, giving the whole hinder part a dark appearance. Antennae 
light ferruginous, yellowish at the base, scarcely annulated. Prothorax longer than broad, with two median fuscous lines broader posteriorly and separated by a distinct paler line; a fuscous streak on either side starting from a black dot on the anterior transverse sulcus; lateral margins narrowly fuscous. Mesoand metanota varjegated with yellowish and fuscous markings, those on former apparently consisting of two narrow median lines with three more or less interrupted lines on either side. Legs yellowish with whitish hairs; anterior femora fuscescent, tibiae of two anterior pairs with a dark median and apical annulation; tarsi annulated with blackish.

Wings: fore wings near the base with about six of the costal cellules subdivided by a cross-vein. Venation white variegated with blackish ; costa pale, costal veinlets pale but black at the margin and sometimes with dark dots in the middle, pterostigma whitish; subcosta marked with black at the insertion of the costal veinlets; radius pale marked with long black dashes at wider intervals; radial sector towards the apex nearly continuously dark; posterior oblique line hardly marked, subapical short but distinct (in both wings); gradate veinlets in apical portion of wing mostly dark, and the axillae of the apical forks and of some of the veins also dark. The hind wings have the venation less marked with blackish except in the apical third; a few of the veinlets running from the oblique stria to the margin being narrowly shaded with fuscous. (Plate II, fig. 3.)

Length of fore wing $25 \mathrm{~mm}$.

1, Qurnah, 17.v.18 (Buxton).

\section{Creagris plumbea Oliv.}

7, Kurnah, 17.v. ; Kut-el-Amara, 7-8.viii., Amara, 14.vi, 20-31.vii, 5.ix.18 (Buxton).

8, Amara, 30.x.17, 16.v., 21.vii, 5-31.viii (at light), 11.ix.18 (on dead vegetation in dried-up marsh 12 miles below Amara) (Evans).

2, Baiji, 3.v, Baghdad, 21.ix.20 (Peile).

7, Kazvin, 17, 20, 31.vii, 8.viii, 7.ix ; Enzeli, 30.vi.19 (Buxton).

This long series is not quite homogeneous. Those from N.W. Persia and those from Mesopotamia differ from each other in facies, the former generally partaking more of the European character and having the venation pale reddish with the darker interruptions often faint, while those from Mesopotamia in fully mature examples have the pale parts of the venation whiter with the dark interruptions standing out in stronger contrast. The markings on the pronotum are variable. In the best marked Mesupotamian specimens the median lines are well defined, sepaiate, strongly bulged outwards behind the anterior transverse sulcus with anterior and posterior prolongations turned outwards; from the latter a small dash directed upwards and inwards (apparently on the line of a short diagonal sulcus); on the anterior transverse sulcus a rounded 
dot on either side of the median lines; posterior to or connected with the dots a short line, thus forming either a comma-like or semicolon-like marking. The lateral margins in great part marked with a dark line. The pale space between the median lines varies in extent and the markings may tend to be in part obsolete, either actually or on account of the immaturity of the specimen.

In many European examples the median lines show little or no pale space between them, and the other markings may be reduced to the dots on the transverse sulcus and dark lateral margins; in others the median lines may show considerable lateral expansion behind the sulcus.

Two larvae of a species of Ant-lion, found by Evans at Amara on desert-ground (ix.18), may belong to this species, which is evidently a common one in the region, although the markings do not fully agree with Meinert's figure of " $M$. pallidipennis" as reproduced by Sharp (op. cit. p. 456).

\section{Creagris irrorata Klug?}

1, Amara, 27.vi.18 (Buxton).

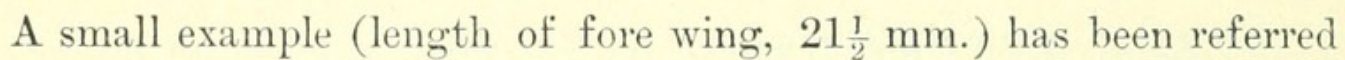
to this species with doubt. The venation is rather strongly variegated with darker spaces, and the markings of the pronotum differ little in general character from those of $C$. plumbea from the same region.

\section{Myrmecaelurus trigrammus Pallas.}

4 우 은 Kazvin, 27.vii, 5.viii, 24, 29.viii.19, stony desert, $4000 \mathrm{ft}$. (Buxton).

\section{Myrmecaelurus atrox Walker.}

1 ㅇ, Amara, 17.vi.18 (Evans); 1 으, Kizil Robat, left bank of R. Dyala, 25.vi.19 (Peile). Mr. Herbert Campion has at my request compared the latter with two specimens in the British Museum, both carrying type labels, standing over the name Myrmeleon atrox and agrees with the determination.

\section{Myrmecaelurus sp.?}

1 q , 1920, Mesopotamia, without further indication of locality (Peile).

Head and greater part of the body crushed. Pronotum with three lines, the median interrupted at the sulcus, the lateral lines only reaching thereto, meso- and metanotum with broad black median and lateral lines. Abdomen apparently with black dorsal line and light interrupted lateral lines; blackish beneath. Legs yellow, femora lightly fuscescent externally, with tarsi black at the apex. Wings subacute, hyaline, venation mostly black with whitish 


\title{
G. A. BENTALL,
}

NATURAL SCIENCE ESTABLISHMENT

(ENTOMOLOGY),

Dudley House, Southampton St., Strand, London, W.C.2.

\section{ENTOMOLOGICAL SUPPLIES OF ALL KINDS.}

Reduction in Prices of Glass-bottomed Boxes.

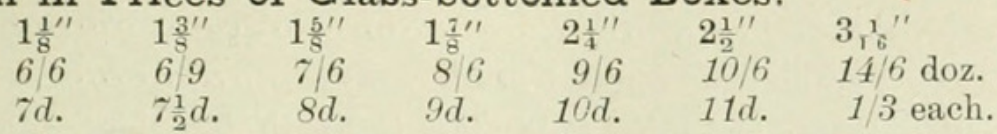

New material in Hymenoptera, Hemiptera-Homoptera, Orthoptera, Odonata, and Diptera from the West Indies and British Guiana.

Large Collection of African Cetonids and Longicorn Coleoptera just received.

New Section.-Palaearetic and Exotic Birds' Skins and Eggs, also Reptiles.

September, 1921 .

REVISED PRICES FOR BACK VOLUMES.

1st Skries, 1864-1889.-Parts, 3/6 net each; Volumes, 22/6 net,

Vols. 1 to 25 .

bound $3 / 6$ extra.

These can be obtained in many cases in complete Volumes. Nany of the single parts ean also be supplied separately. Particulars on application to the Publishers.

2ND Series, 1890-1914.-Parts, $2 / 6$ net each; Volumes, 20 - net each, Vols. 1 to 25 (Vols. 26 to 50 of the entire Series).

bound $3 / 6$ extra.

3rd Series, Vol. 1 (1915).--Parts, 2/6 net each; Vols. $17 / 6$ net each, bound $3 / 6$ extra.

,, 2 (1916).- ,, 2/6 net each; Vols. 17/6 net each, bound $3 / 6$ extra. , 3 (1917).- ,, 2/6 net each; Vols. 17/6 net each, bound $3 / 6$ extra , 4 (1918).— , 2/6 net each; Vols. 17/6 net each, bound $3 / 6$ extra. , 5 (1919).— , 26 net each; Vols. 17/6 net each, bound $3 / 6$ extra , 6 (1920).- , 26 net each; Vols. $17 / 6$ net each, bound $3 / 6$ extra.

SubSCRIPTION FOR 1921 (payable in advance), 15-net, post free.

Cloth cases for binding the 1920 Volume can be supplied at $2 /-$ net, post free. All applications for the above should be made to-

Messrs. GURney \& JaCKson, 33 Paternoster Row, London, E.C. 4.

\section{NATURAL HISTORY.}

We keep in Stock everything required by

\section{COLLECTORS OF BIRDS' EGGS, INSECTS, PLANTS, F.tc.}

\author{
CATALOGUES FREE.
}

WATHINS \& DONGASTER, 36 Strand, London, W.C. 2, England 
Observations on British Coccidae, with descriptions of new species (with figures).

No. VI. (concluded).-L. E. Green, F.Z.S. 193

Some Indian Coleoptera (with figures) (6) (concluded).-G. C. Champion, F.Z.S. 201 A new genus and species of Orthoptera found in a greenhouse in England.-

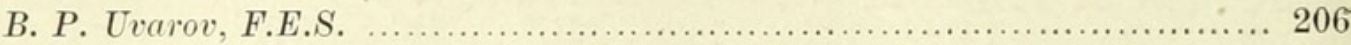

A black variety of Papilio machaon in Norfolk.-Eds....................... 209 Heptaulacus villosus Gyll. and other Coleoptera in North Yorkshire.-Di. M. L.

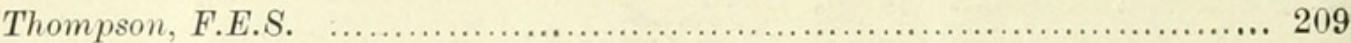

Clytochrysus planifrons Thoms. at Penarth.-H. M. Hallett, F.E.S. ............ 210

Methoca ichneumonides Latr. and other Hymenoptera in Glamorgan. - Id. ..... 210

The tibial comb of Deraeocoris Kirschb. (=Capsus and Camptobroch:s Fieb.).--

G. C. Champion, F.Z.S. ............................................. 210

Oviposition of Aphelinus chaonia Walker. G. J. Arrow, F.E.S................ 211 Review. "Insect Pests of Farm, Garden, and Orchard." By E. Dwight

Anderson. Second edition revised and enlarged by Leonard Marion

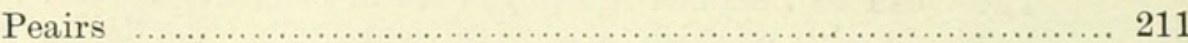

SocIETy.-Entomological Society of London ................................ 212

Neuroptera, Mecoptera, and Odonata from Mesopotamia and Persia.-K. J.

Morton, F.E.S.

\section{THE I A T U A I I T:}

A MONTHLY II.LUSTRATED JOURNAL OF

\section{NATURAL HIS'TORY FOR THE NOR'TH OF ENGLAND EDITED BY}

T. SHEPPARD, M.Sc., F.G.S., F.R.G.S., F.S.A.Scot., The Museum, Hull;

AND

T. W. WOODHEAD, Ph.D., M.Sc., F.L.S., Technical College, Heddersfield ;

IVITH THE ASSISTANCE AS REEEREES IN SPECIAL DEPARTMENTS OF

GEO. T. PORRITT, F.L.S., F.E.S., JOHN W. TAYLOR, M.Sc., RIJEY FORTUNE, F.Z.S.

The Journal is one of the oldest Scientific Periodicals in the British Isles, dating back to 1833, and is circulated widely amongst the principal Naturalists of the country.

London: A. Brown and Sons, Limited, 5, Farringdon Avenue E.C. 1. And at Hull and York.

PRICE, 9d. NET. Prepaid Subscription, $8 / 6$ per annum. 
The Annual Subscription for 1921 is $15 /-$.

Third Series. N0. 82.]

[No. 689.]

OCTOBER, 1921. [PRICE 2/- NFT.

TH E

ENTOMOLOGIST'S

NOSTIIL WLGAZINE.

EDITED BY

G. C. CHAMPION, F.Z.S. J. E. COLLIN, F.E.S.

W. W. FOWLER, D.Sc., M.A., F.L.S.

R. W. LLOYD, F.E.S. G. T. PORRITT, F.L.S.

J. J. WALKER, M.A., R.N., F.L.S.

\section{VOLUME LVII.}

[THIRD SERIES-VOL. VII.]

“J'engage donc tous à éviter dans leurs écrits toute personnalité, toute allusion dépassant les limites de la discussion la plus sincère et la plus courtoise."-Laboulbène.

\section{O N D O N :}

GURNEY \& JACKSON (Mr. VAN Voorst's SUCCEssors), 33, PATERNOSTER ROW, E.C. 4. 
The price of the Magazine is $15 /-$ per annum to Subscribers and 2/- a part for single copies.

Subscriptions for 1921 are now due and should be remitted as soon as possible to

R. W. LlOYD, I. 5, Albany, Piccadilly, London, W.1.

\section{SCALE OF CHARGES FOR ADVERTISEMENTS.}

Whole Page.....£6. Half Page.....£ 3 s Quarter Page.....£1 14s.

Lowest charge, 10s, 6 d. up to 5 lines; 1s. 6 d. per line afterwards.

Repeated or continuous Advertisements per contract.

There is no charge for Lists of Duplicates or Desiderata.

All payments and applications for the above should be made to

R. W. LLOY D, I. 5, Albany, Piccadilly, W. 1.

AUTHORS are requested to send their communications and proofs to either

J. J. Walker, Aorangi, Lonsdale Road, Summertown, Oxford; or G. C. Champion, Broomhall Road, Horsell, Woking.

Desiderata.-Wanted, British and Exotic Orthoptera; Locusts, Stick Insects, Leaf Insects, etc. Liberal exchange or Cash. L. SuggrtT, 16 Williamson Lane, Droylsden, Manchester.

Desiderata.-Tetropium gabrieli, T. crawshayi, T. parcum, Hylotrupes bajulus, Molorchus umbellatarum, Rhagium indagator, Pachyta 6-maculata, P. collaris, Leptura fulva, Strangalia aurulenta, Acanthocinus aedilis, Pogonochaerus bidentatus, Lamia textor, Saperda scalaris, Stenostola ferrea, Oberea oculata.--N.C.RoтнschiLD, 4 Palace Green, London, W. 8.

\section{FOR SALE.}

Tropical African (Uganda \& Kenia Colony) Butterflies \& Moths, etc., etc., in Great Variety and A 1 Condition (papered).

Special OfFer : -200 specimens of 50 species at $£ 6$ the lot. Cash with order. -R. A. Dummer, c/o S.A. Museum, Cape Town.

\section{MEETINGS OF SOCIETIES.}

ENTOMOLOGICAL SOCIETY OF LONDON, 41 Queen's Gate, S.W.7 (nearest stations: South Kensington and Gloucester Road).- October 5th, 19th, at 8 p.m.

The Library is open daily from 9 a.m. to 6 p.m. (except on Saturdays, when it is closed at 2 p.m.), and until 10 p.m. on Meeting nights.

THE SOUTH LONDON ENTOMOLOGICAL AND NATURAL HISTORY SOCIETY, Hibernia Chambers, London Bridge. The Second \& Fourth Thursdays in each month, at 7 p.m. The lantern will be at the disposal of Members for the exhibition of slides.

THE LONDON NATURAL HISTORY SOCIETY, now meets in Hall 40 Winchester House, Old Broad Street, E.C. 2, on 1st and 3rd Tuesdays in the month at 6.30 p.m. General meetings 1 st Tuesdays, Sectional meetings $3 \mathrm{rd}$ Tuesdays. (No meetings in July or August indoors, but field excursions instead.)

Hon. Sec.: W. E. Glegg, 44 Belfast Road, Stamford Hill, N. 16.

Chingford Branch. The Chingford Local Branch meets at the Avenue Café, opposite C'hingford Station, at 8 p.m., on the 2nd Monday in each month. 
interruptions on the main veins; subcosta black at each costal veinlet, radius with longer black and white spaces; costal veinlets in basal portion of fore wings black on margin only ; transverse veinlets mostly black in apical half of wing, mostly pale nearer the base; in all the wings a minute black dot at the rhegma and traces of a dot on $\mathrm{Cu}_{1} \mathrm{p}$ before the margin. In radial field before the sector 6 transverse veinlets in fore wings and 5 in hind wings. Radial sector arising considerably beyond furcation of $\mathrm{Cu}_{1}$.

Length of fore wing $25 \mathrm{~mm}$, hind wing $23 \mathrm{~mm}$.

I have not given a name to the above example, as Navás has described quite a number of species of this genus which I have not seen. He mentions at least two which have dots at the rhegma, viz. : M. trigrammus var. obscura from Ouanda, British Somaliland (Mem. Real Acad. de Ciencias y Artes, vol. xi, No. 13, p. 197, 1914), and $M$. dioristus from Obock (Mem. d. Pontificia Accad. Romana, vol. xxxii, Neuropt. Nova Africana, p. 103, 1914).

\section{Cueta lineosa Ramb.}

1 , , Baghdad, 30.ix.17; 2 우 우, 16, 18.vi, 2 ㅊ o , 15.vi, 13.ix.18, Amara ; 1 ơ, Kut-el-Amara, 9.viii.18 (Buxton).

5 우 $\delta^{\circ}, 2$ 우 오, Amara, 3.v (at light in room), 17.vi., 21.vi ; near Chahala, 5 miles below Amara, 29.viii.18 (Evans).

1 ㅇ, Kazvin, 19.viii.19, at light (Buxton).

\section{Cueta syriaca Navás?}

1 \&, Kirkuk, 2.x.19 (Peile). Differs from C. lineosa in the more rounded apex of the wings and the markings on the abdomen. Agrees fairly well with Navás's description, but is referred to his species with some hesitation, as Petersen considers $C$. syriaca to be the same as C. lineosa.

\section{Morter hyalinus Oliv.}

1, Kut-el-Amara, 7.viii.18 (Buxton); 6, Amara, 10.v, 21.vii, 17.viii ; near Chahala, 29.viii.18 (Evans).

1, Fathah, right bank of R. Tigris, 18.vii.20 (Peile).

Myrmeleon inconspicuus Ramb.

1, Enzeli, 21.vi; 1, Tula Rud, 5.vii.19 (Buxton).

\section{Gepus buxtoni, n. sp.}

Testaceous with blackish markings. Face yellowish with an obscure interrupted line from between the antennae to the clypeus (antennae mutilated); a blackish line behind the antennae followed by a pale space and then by a 
dark line, behind which there seems to be another obscure line and other markings. Prothorax with heavy black median line (continued with interruptions to the end of the abdomen), lateral margins blackish ; between the lateral markings and the median line an interrupted narrow line. Mesothorax : praescutum with two somewhat wedge-shaped markings on either side of the median line, scutum with interrupted lines, and scutellum with the median line distinct and two black points near its base. Legs: tibiae of two anterior pairs with black annulation at base, middle, and apex; posterior pair at apex only; tarsi annulated with black. Abdomen with interrupted dorsal line and rather broad waved lateral lines with short streaks between.

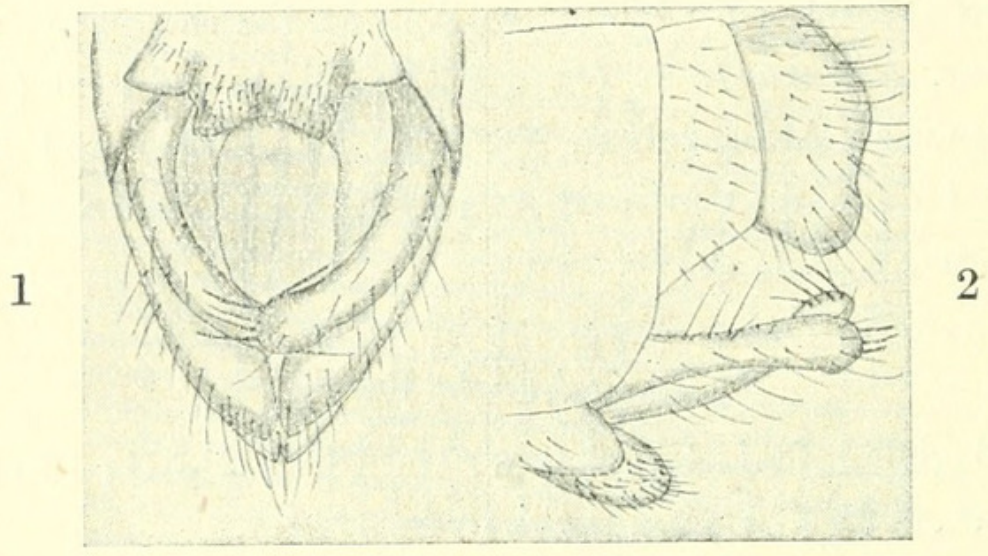

Fig. 1.-Apex of abdomen from beneath of Gepus buxtoni, 오. 2.-Apex of abdomen from side of Gepus buxtoni, 오.

Wings : fore wing cross-veinlets in 9 to 11 costal cellules proximal to the pterostigma. Venation white, with blackish or brownish interruptions. Many of the costal veinlets with a dark dot in the middle and also at the point at which they anastomose with the costa. Pterostigma yellowish, with three black veinlets on the proximal side. Subcosta with a blackish dash at the base of each costal veinlet up to about the pterostigma. Radius marked with long black dashes alternating with pale intervals up to its joining the subcosta. Rs and branches, also cubiti and branches, with long black dashes; oblique lines (anteapical and on inner margin) present; most of the marginal forks shaded. Colour scheme of hind wings similar, but less strongly marked. (Plate II, fig. 2.)

Length of fore wing $35 \mathrm{~mm}$., hind wing $31 \mathrm{~mm}$.

1 ㅇ, Basra, 18.viii.18 (Buxton).

\section{Gepus invisus Navás.}

1 o , Kut-el-Amara, 9.viii.18 (Buxton).

In referring this $\delta$ to the above species I have followed Petersen. In the wing-markings it agrees almost perfectly with an Egyptian $q$ so named by that author, but it differs in having double rows of cells between some of the branches of $\mathrm{Cua}_{1}$. The wing-markings also agree with Navás's figure of $G$. curvatus, which was originally described 
as the $q$ of $G$. invisus, and which Petersen is still disposed to consider the same as the latter species.

The cross-veinlets in the costal area of the fore wing of $G$. buxtoni seem to exclude any possible association of the same with this $\sigma^{*}$.

The genus is remarkable for the rounded projection at the base of the anterior wing and for the swollen scutellum of the mesonotum.

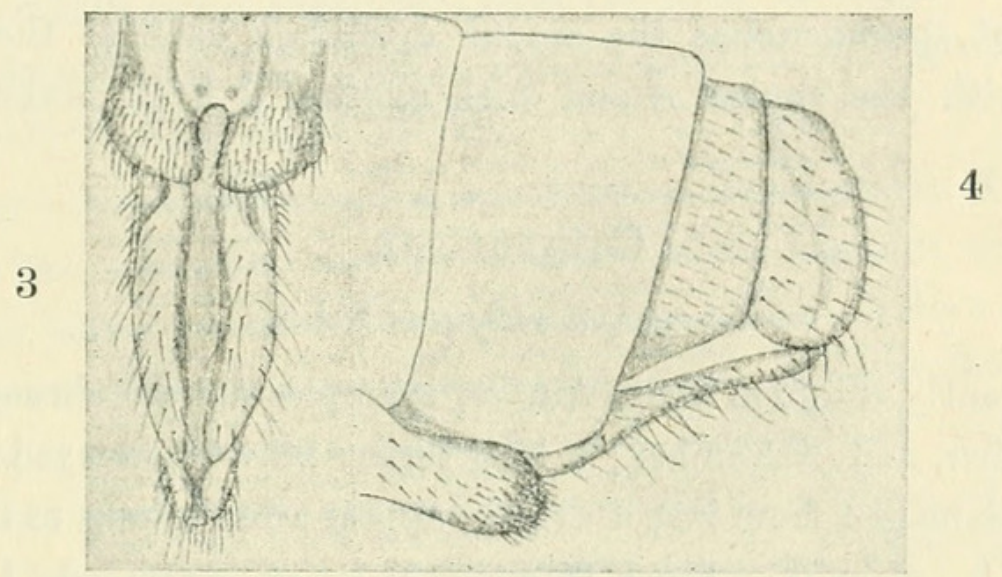

Fig. 3.-Apex of abdomen from beneath of Gepus invisus, $q$. 4.-Apex of abdomen from side of Gepus invisus, 오.

For the sake of comparison, I give figures of the apex of the abdomen of a 9 from Egypt (Ballah, 1.viii.16) kindly given me by Mr. Storey.

The wings of the of are figured on Plate II, fig. 1.

Acanthaclisis pallida McLach.

1 q , Amara, 10.viii.18 (Buxton).

Has been recorded from South Russia and Western Asia.

\section{NeMOPTERIDAE.}

\section{Halter halteratus Forskal.}

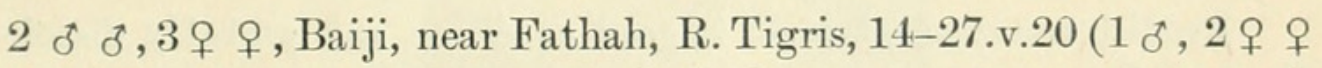
"at light," and 1 o settled on leaf of Capparis spinosa at 7 A.M.), 3 오 오, Mirjana, R. Djala, 27-30.v.19, "at light” (Peile).

\section{Kirbynia extensa Oliv.}

1 ㅇ, Mirjana, 1.vi.19, among grass and flowers, bank of river"one like this on thistles and other flowers" (Peile).

In his Mon. de los Nemopteridos (Mem. Real Acad. de Ciencias y Artes, Barcelona, 1910, p. 386) Navás figures the hind wing of o type 
(Mus. Paris) with the second dilatation dark at the tip, while the $q$ also figured (Mus. Vienna) has the dilatation pale at the tip. The latter is presumably from the Araxes Valley, Caucasus, and Navás proposed the name litigiosa in the event of its proving different from K. extensa. In his later revision of the Nemopteridae (Genera Insectorum, 1912, p. 14) he raises his subgenus Olivierana to generic rank, and says that he has seen other examples which have dissipated any doubts that he had as to the identity of the specimens from the Caucasus with $K$. extensa. The present specimen has the second dilatation dark at the tip, thus agreeing with the typical o and with another of from Malatia in my collection.

\section{Chrisopidae.}

\section{Chrysopa vulgaris Schn.}

Apparently common about Amara, examples dated February, March, May, October, and November; a long series, 28.v.18, delayed in transit and much damaged from insect attack, appear all to belong to this species (Buxton \& Evans); Jebel Hamrin, N.E. of Baghdad, 1, 30.xi.18 (Evans); Resht 1, 18.ii, Enzeli 1, 24.v, Kazvin 2, 17-31.vii.19 (Buxton).

\section{Chrysopa septempunctata Wesm.}

1, Enzeli, 30.vi.19 (Buxton).

\section{Chrysopa abbreviata Curt.}

\section{1, Enzeli, 12.vi.19 (Buxton).}

\section{Chrysopa sp.?}

1, Amara, 24.ix.18, at light (Buxton). A very small species (fore wing about $7 \mathrm{~mm}$.), not in good condition, which in the meantime remains undetermined.

\section{Chrysopa tigridis, n. sp.}

Reddish testaceous, but not in good condition and probably discoloured. Head reddish, markings uncertain; antennae (incomplete) slender, pale with fuscous lines above and externally on basal and second joints. Legs (anterior and intermediate incomplete) whitish, tarsi with short black spines.

Wings vitreous; venation mainly whitish, with brownish dots and spots in fore wings, most of the costal veinlets pale in the middle only; veinlets between radius and sector strongly margined with brown anteriorly; dark dots mostly where transverse veinlets anastomose with main veins and at the termination of marginal forks ; eight rather conspicuous dark blotches-namely, at pterostigma, at apex of wing near termination of radial sector, at outer margin, at gradate series of veinlets, at base of radius, and three on inner margin, the 
subbasal one being clear in the middle. In hind wings the costal veinlets entirely dark ; smiall blotches at pterostigma, near apex of radius, and subbasal on inner margin. (Plate II, fig. 4.)

Length of fore wing $10 \mathrm{~mm}$.

A single specimen, Amara, 1tth September, 1918 (Buxton).

Allied to C. fedtschenkoi MeLachl. Although the colours and markings of the body in the type are not in a satisfactory condition, the species should be easily recognized from the wing-markings. The minute particles dusted over the wings in the photograph are apparently due to the presence of adventitious matter.

NoтE.--Since the foregoing was written, Mr. Campion of the British Museum has submitted another example of $C$. tigridis, in which the colours are better preserved than in the type. Frons with a reddish line under the antennae; a black line on the genae; clypeus laterally edged with black; raised vertex bordered with reddish and apparently two faint brownish median lines; middle of dorsal surface of thorax and abdomen pale; pronotum rather broadly margined with brownish, the dark margins with short black spinose hairs; indistinct brownish linear markings on meso- and metanotum.-Daurah, R. Tigris, June 1920, along with a specimen of Helicomitus dicax, both taken by Major A. D. Fraser.

\section{HeMerobitd AE.}

\section{Boriomyia persica, n. sp.}

o. Similar in appearance to other species of the nervosa group: three radial sectors in type.

Head yellowish above, face shining brownish; thorax above yellowish,

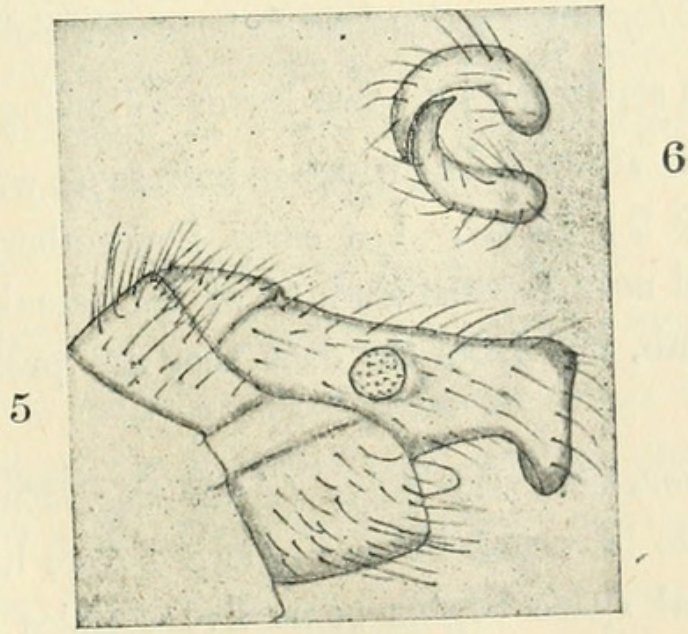

Fig. 5.-Apex of abdomen from side of Boriomyia persica, $\delta^{\star}$.

6.-Apex of appendages of Boriomyia persica, of, from beneath. 


\section{$2 \mathrm{BHL}$ Biodiversity Heritage Library}

Morton, Kenneth J. 1921. "Neuroptera, Mecoptera, and Odonata from Mesopotamia and Persia." The Entomologist's monthly magazine 57, 213-225. https://doi.org/10.5962/bhl.part.22331.

View This Item Online: https://www.biodiversitylibrary.org/item/36035

DOI: https://doi.org/10.5962/bhl.part.22331

Permalink: https://www.biodiversitylibrary.org/partpdf/22331

\section{Holding Institution}

Smithsonian Libraries

\section{Sponsored by}

Smithsonian

\section{Copyright \& Reuse}

Copyright Status: NOT_IN_COPYRIGHT

This document was created from content at the Biodiversity Heritage Library, the world's largest open access digital library for biodiversity literature and archives. Visit BHL at https://www.biodiversitylibrary.org. 